\title{
Diversity of gastropods in the inland waterbodies of Western Siberia
}

\author{
M.V. Vinarski', S.I. Andreeva ${ }^{1}$, N.I. Andreev ${ }^{2}$, \\ E.A. Lazutkina ${ }^{1}$, A.V. Karimov ${ }^{1}$
}

\begin{abstract}
${ }^{1}$ Museum of Siberian Aquatic Molluscs, Omsk State Pedagogical University, Tukhachevskogo emb., 14, 644099 Omsk Russia.e-mail: radix@omskcity.com

${ }^{2}$ Omsk State Railway University, K. Marx ave., 35, 644046 Omsk Russia. e-mail: nik_andreyev@mail.ru
\end{abstract}

ABSTRACT: The results of long-term (1973-2005) authors' studies of the inland water gastropod of Western Siberia are given. Following to the most recent taxonomic surveys (Starobogatov et al., 2004; Kantor, Sysoev, 2005), we count 134 gastropod species belonging to nine families to dwell in the region under discussion. Most of them ( 86 out of 134) are pulmonates. The most diverse fauna of water snails was found in the Irtyshian zoogeographical province, and the least diverse - in the Lower Obian one. There is a clear latitudinal gradient of gastropod species richness in Western Siberia. Differences in species composition between zoogeographical provinces as well as possible pathways of snails' migration through Western Siberia are discussed. It was found, the gastropod fauna of Western Siberia inland waters has a European origin with a participation of autochtonous species and migrants from Eastern Siberia and Northern America.

KEYWORDS: inland water gastropods, Western Siberia, malacofauna, zoogeography.

\section{Разнообразие брюхоногих моллюсков континентальных водоемов Западной Сибири}

\section{М.В. Винарский', С.И. Андреева ${ }^{1}$, Н.И. Андреев ${ }^{2}$, Е.А. Лазуткина ${ }^{1}$, А.В. Каримов ${ }^{1}$}

\footnotetext{
${ }^{1}$ Музей водных моллюсков Сибири при Омском государственном педагогическом универсиmете, наб. Тухачевского, 14, 644099 Омск Россия.е-mail: radix@omskcity.com

${ }^{2}$ Омский государственный университет путей сообщения, пр. Маркса, 35, 644046 Омск Poccuя.e-mail: nik_andreyev@mail.ru
}

РЕЗЮМЕ: В статье изложены результаты многолетних (1973-2005 гг.) исследований авторов, посвященных пресноводным гастроподам Западной Сибири. Следуя современным таксономическим монографиям и обзорам (Старобогатов и др., 2004; Кантор, Сысоев, 2005), мы насчитываем в составе малакофауны Западной Сибири 134 вида пресноводных моллюсков, относящихся к девяти семействам. Большая часть видов (86 из 134) принадлежит подклассу Pulmonata. Наибольшее видовое разнообразие водных гастропод выявлено в Иртышской зоогеографической провинции, наименьшее - в Нижнеобской. В Западной Сибири установлен четко выраженный широтный градиент видового богатства водных брюхоногих моллюсков. Об- 
суждаются различия в видовом составе отдельных зоогеографических провинций, а также возможные пути миграции моллюсков по территории Западной Сибири. Установлено, что фауна водных гастропод Западной Сибири имеет европейское происхождение, в ней есть также автохтонные виды и виды, мигрировавшие из Восточной Сибири и Северной Америки.

КЛЮЧЕВЫЕ СЛОВА: брюхоногие моллюски континентальных вод, Западная Сибирь, малакофауна, зоогеография.

\section{Introduction}

The history of studying of the Western Siberian continental malacofauna started more than 170 years ago, when F. Gebler (1829) published his brief list of mollusc species which were kept in the Barnaul Museum. In the XIX century, several prominent scientists (A.F. Middendorff, C.A. Westerlund, I.D. Czerski were among them) have explored molluscs of the Western Siberian waterbodies (Westerlund, 1877, 1884, 1897; Mozley, 1936). However, down to the middle of the XX century investigations in this area were rather sporadic, and the greater part of Western Siberia has remained not surveyed by malacologists. V.I. Zhadin used these incomplete and desultory data on the Western Siberian water gastropods in his well-known monograph on fresh- and brackish water Mollusca of the former USSR (Zhadin, 1952), where he listed 34 species of snails inhabiting the region under discussion (Table 1).

The first attempt to realize a complete and comprehensive survey of the Western Siberian water malacofauna was undertaken by the Tomsk hydrobiological school under leadership of Prof. B.G. Johansen in the 1950-1970s. B.G. Johansen and his disciples (E.A. Novikov, V.N. Dolgin, V.A. Gundrizer, E.S. Frolova) explored different parts of the region and published a great number of papers devoted to species composition, taxonomy, ecology and practical significance of freshwater molluscs (Novikov, 1971; Frolova, 1973; Dolgin, Johansen, 1976; Gundrizer, 1984 and others). As a result of this work, E.A. Novikov (1983) published a concise report where he estimated diversity of Western Siberia freshwater gastropods. In total, he count- ed 89 species of snails in the waterbodies of the region (see Table 1).

Species interpretations and nomenclature used by B.G. Johansen's school corresponded to the state of malacological taxonomy of those days. Since the latter half of the 1960s, a numerous taxonomic issues by Ya.I. Starobogatov and his collaborators and disciples began to be published. To date, the traditional system of most families of palaearctic freshwater molluscs has undergone a drastic change (Starobogatov, 1994). In particular, the number of species and genera, which are thought by Ya.I. Starobogatov's school to be valid is several times more than the analogous numbers that their colleagues in Western Europe can recognize (see MeierBrook, 1993; Starobogatov, 1994; Korniushin, 2002 for review). From the point of view of Ya.I Starobogatov's school, many of those species, which are accepted by Zhadin (1952) as well as by modern Western European taxonomists (Glöer, 2002; Glöer, Meier-Brook, 2003), are, in reality, complexes of species, and should be split into several taxa of a species rank (Kruglov, Starobogatov, 1987; Starobogatov, 1994).

As a result of these changes, a need for repeated faunistic inquiry of inland water gastropods of Western Siberia has arisen. Moreover, some geographic subregions of this territory have not been ever included into a malacofaunistic survey.

Here we present, in a brief form, the main results of our long-term taxonomic and faunistic study devoted to fresh- and brackish water gastropods of Western Siberia. While studying, we took into consideration all the taxonomic novelties that were offered in 1970-2000s by Ya.I. Starobogatov and his school (see Starobogatov 
Table 1. Diversity of gastropods in the inland waterbodies of Western Siberia Таблица 1. Разнообразие брюхоногих моллюсков континентальных вод Западной Сибири

\begin{tabular}{|l|c|c|c|}
\hline \multirow{2}{*}{ Family } & \multicolumn{3}{c|}{ Number of species according to different authors } \\
\cline { 2 - 4 } & V.I. Zhadin (1952) & E.A. Novikov (1983) & Own data \\
\hline \multicolumn{4}{|c|}{ subclassis Pectinibranchia (= Prosobranchia auct., partim) } \\
\hline Viviparidae & 1 & 1 & 1 \\
\hline Valvatidae & 2 & 13 & 25 \\
\hline Hydrobiidae & 1 & - & 14 \\
\hline Bithyniidae & 2 & 6 & 8 \\
\hline \multicolumn{4}{|c|}{ subclassis Pulmonata } \\
\hline Acroloxidae & $1^{*}$ & 1 & 4 \\
\hline Bulinidae & \multirow{2}{*}{$6^{* *}$} & 3 & 33 \\
\hline Planorbidae & 9 & 24 & 40 \\
\hline Lymnaeidae & 2 & 36 & 8 \\
\hline Physidae & $\mathbf{3 4}$ & 5 & $\mathbf{1 3 4}$ \\
\hline Total & & $\mathbf{8 9}$ & \\
\hline
\end{tabular}

*Zhadin (1952) includes the genus Acroloxus into the family Ancylidae

**Zhadin (1952) includes the family Bulinidae into the family Planorbidae s.lato

et al., 2004; Kantor, Sysoev, 2005 for review). Thus, our species list is the third attempt, after V.I. Zhadin (1952) and E.A. Novikov (1983), to estimate an overall species diversity of snails of the continental waters of Western Siberia. It should be noted, however, that there are many taxonomic and nomenclature problems with Siberian water molluscs to be resolved in further studies. Therefore our results should be regarded only as interim ones and these are opened for eventual subsequent alterations and additions.

\section{Material and methods}

The base of the investigation was authors' own field studies that were carried out during years 1973-2005 in different parts of Western Siberia (Tomsk, Novosibirsk, Omsk, Altay and Tyumen Regions, Northern and Central Kazakhstan). All malacological materials collected by the authors are stored in the Museum of Siberian Aquatic Molluscs (established in 2003 as a scientific sub-unit of the Omsk State Pedagogical University). In whole, these collections include more than 60000 specimens of molluscs, both gastropods and bivalves. Besides, we had an opportunity to examine a large collection of molluses gathered by Dr. V.N. Dolgin (Tomsk) in the waterbodies of the north- ern part of Western Siberia. A small part of this collection is stored in the Museum of Siberian Aqua-tic Molluscs as well as collections of Dr. D.A. Razmashkin, A.V. Ubasskin, A.V. Panin, P.V. Chashchin and other researchers. In addition, we examined the largest malacological collections of Russia. The collections of the Zoolo-gical Institute of RAS (Saint-Petersburg), of the Zoological Museum of the Institute of Plant and Animal Ecology of RAS (Yekaterinburg) and of the Biology and Biophysics Research Institute of the Tomsk State University are among them. These collections are originated from all parts of Western Siberia and include samples that have been made from the 1840 s to date.

It is worth to note, we apply the term 'Western Siberia' in a somewhat unusual sense, otherwise than geographers commonly do (see, for example, Richter, 1963). In addition to the waterbodies situated in the Western Siberian plain, those of the eastern mountside of the Urals have been included into the scope of our study, whereas we have not explored the territory of Altay Mountains. The Altaian malacofauna is distinct from that of adjacent lowland regions by its origination and by a high degree of endemism. It is more similar to the malacofauna of Western Mongolia and Upper Yenisei drainage basin than to the malacofauna of the Western Siberia 


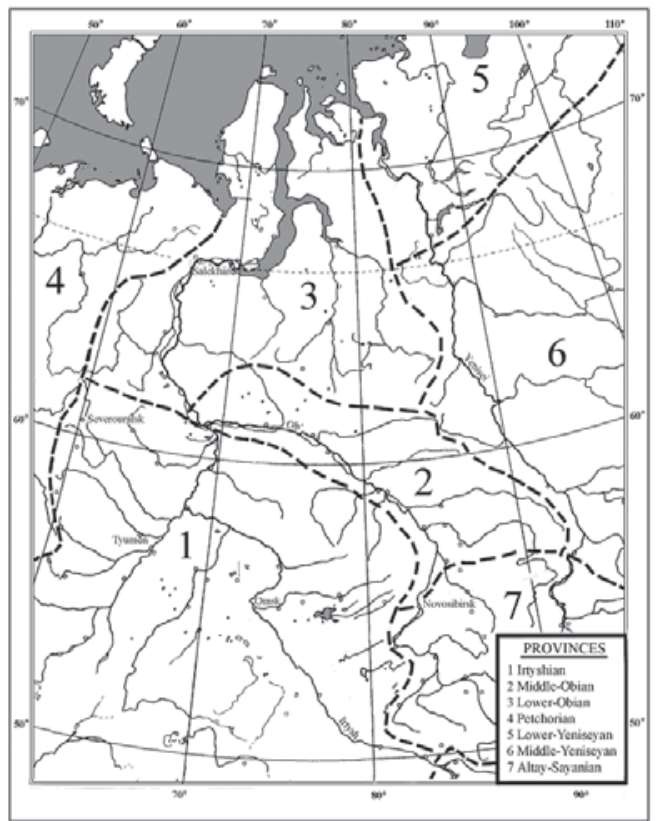

Fig. 1. Zoogeographical zonation of the Western Siberia territory (according to Starobogatov, 1986, with additions after Dolgin, 2001).

Рис. 1. Зоогеографическое районирование территории Западной Сибири (по Старобогатову, 1986, с дополнениями по Долгину, 2001).

plain. According to Ya.I. Starobogatov's zoogeographic zonation (Starobogatov, 1986), the territory that we designate here as "Western Siberia' belongs to three provinces: Irtyshian (IRT), Middle Obian (MOB) and Lower Obian (LOB) (Fig. 1).

The species identification was carried out using both conchological and anatomical features. We followed the recent key (Starobogatov et al., 2004) in delimitation of species, and Catalogue of Russian molluscs (Kantor, Sysoev, 2005) in their naming. Always, when it was possible, we used the type series of species from the collection of the Zoological Institute of RAS as well as original descriptions of taxa. During our work, we obtained frequent advice of the late Dr. Ya.I Starobogatov who has confirmed some of our faunistic findings.

We used the Ochiai's index of association (Ochiai, 1957; Pesenko, 1982) as a measure of faunistic similarity between zoogeographical provinces. This index is similar to well-known indices of Jaccard and Czekanowski-Sörensen, but it utilizes the geometric mean instead of the arithmetic one, and this is considered as an advantage of the Ochiai's index (Malyshev, 2001). For the comparative analyses we used lists of species inhabiting two other faunistic provinces adjacent to Western Siberia: Pechorian (Leshko, 1998; Leshko et al., 2001) and Lower Yenisean (Gundrizer, 1984; Dolgin, 2001).

\section{Results and discussion}

In total, 134 species of Gastropoda are recorded to date in the inland waterbodies of Western Siberia (Table 1, 2). These species belong to nine families, one of which (Hydrobiidae) occurs in brackish lakes of Northern and Central Kazakhstan only. The rest are freshwater dwellers. Our species list is well longer than both by V.I. Zhadin (1952) and E.A. Novikov (1983), and this is due to the recent changes in molluscan taxonomy (see Materials and methods) rather than because of describing of new species.

Species richness of water pulmonates in Western Siberia exceeds significantly that of pectinibranch (=prosobranch) gastropods (86 vs. 48 species, respectively), and such a disproportion is common for the malacofaunas of temperate zone of Northern Hemisphere (Starobogatov, 1970).

The most diverse fauna of water snails was found in the Irtysh River basin (i.e. Irtyshian province), that covers the south-western part of the region, and the least diverse fauna was found in Lower Obian province, that is the northernmost one, and stretches to the shore of the Kara Sea (see Table 2). The overall species richness of water snails decreases along a latitudinal transect and reaches its minimum north of the Arctic Circle. This fact corresponds well to modern ideas on the spatial diversity gradients (Starobogatov, 1970; Chernov, 1991; Gaston, 2000), in particular, to the energy-based hypothesis (Hawkins et al., 2003), which explains the decreasing of species richness from the 
Table 2. Check-list of gastropods of the Western Siberia inland waters Таблица 2. Видовой состав брюхоногих моллюсков континентальных вод Западной Сибири

\begin{tabular}{|c|c|c|c|}
\hline \multirow{2}{*}{ Species } & \multicolumn{3}{|c|}{ Province } \\
\hline & IRT & MOB & LOB \\
\hline \multicolumn{4}{|l|}{$\begin{array}{ll} & \text { family Viviparidae Gray, } 1847 \\
\end{array}$} \\
\hline 1. Contectiana listeri (Forbes et Hanley, 1849) & + & + & - \\
\hline \multicolumn{4}{|l|}{ family Valvatidae Gray, 1840} \\
\hline 2. Valvata (Valvata) cristata (Müller, 1774) & + & + & - \\
\hline 3. V. (Microcincinna) andreaei Menzel, 1904 & + & - & - \\
\hline 4. V. (M.) geyeri Menzel, 1904 & + & - & - \\
\hline 5. V. (M.) trochoidea Menke, 1846 & + & - & - \\
\hline 6. Cincinna (Cincinna) piscinalis (Müller, 1774) & + & + & + \\
\hline 7. C. (C.) obtusa (Draparnaud, 1801) & + & - & - \\
\hline 8. C.(C.) lilljeborgi (Westerlund, 1897) & + & - & - \\
\hline 9. C. (C.) ambigua (Westerlund, 1873) & + & - & - \\
\hline 10. C. (C.) antiqua (Morris in Morris et Sowerby, 1838) & + & - & - \\
\hline 11. C. (C.) falsifluviatilis Starobogatov in Anistratenko, 1998 & + & + & - \\
\hline 12. C. (C.) dilatata (Eichwald, 1830$)$ & + & + & - \\
\hline 13. C. (C.) antiquilina (Mozley, 1934) & + & + & - \\
\hline 14. C. (C.) skorikovi (Lindholm, 1911) & + & + & - \\
\hline 15. C. (C.) chersonica Chernogorenko et Starobogatov, 1987 & + & - & - \\
\hline 16. C. (Atropidina) kliniensis (Milaschevich, 1881) & + & + & - \\
\hline 17. C. (A.) depressa (Pfeiffer, 1821) & + & + & - \\
\hline 18. C. (A.) discors (Westerlund, 1886) & + & - & - \\
\hline 19. C. (A.) pulchella (Studer, 1820) & + & + & - \\
\hline 20. C. (Sibirovalvata) aliena (Westerlund, 1876) & - & + & + \\
\hline 21. C. (S.) ssorensis (W. Dybowski, 1886) & + & + & + \\
\hline 22. C. (S.) confusa (Westerlund, 1897) & + & + & + \\
\hline 23. C. (S.) helicoidea (Dall, 1905) & - & - & + \\
\hline 24. C. (S.) brevicula (Kozhov, 1936) & - & - & + \\
\hline 25. C. (S.) sibirica (Middendorff, 1851) & + & + & + \\
\hline 26. C. (S.) frigida (Westerlund, 1873) & + & + & + \\
\hline \multicolumn{4}{|c|}{ family Hydrobiidae Stimpson, 1865} \\
\hline 27. Caspiohydrobia borealis Andreeva et Frolova, 1989 & + & - & - \\
\hline 28. C. sogdiana Starobogatov et Izzatulaev, 1974 & + & - & - \\
\hline 29. C. johanseni Frolova, 1984 & + & - & - \\
\hline 30. C. kazakhstanica Starobogatov et Andreeva, 1981 & + & - & - \\
\hline 31. C. aralensis Starobogatov et Andreeva, 1981 & + & - & - \\
\hline 32. C. bergi Starobogatov et Andreeva, 1981 & + & - & - \\
\hline 33. C. behningi Starobogatov et Andreeva, 1981 & + & - & - \\
\hline 34. C. sidorovi Starobogatov et Andreeva, 1981 & + & - & - \\
\hline 35. C. nikitinskii Starobogatov et Andreeva, 1981 & + & - & - \\
\hline 36. C. husainovae Starobogatov, 1974 & + & - & - \\
\hline 37. C. elongata Starobogatov et Izzatulaev, 1974 & + & - & - \\
\hline 38. C. tadzhikistanica Starobogatov et Izzatulaev, 1974 & + & - & - \\
\hline 39. C. coniformis Starobogatov et Izzatulaev, 1974 & + & - & - \\
\hline 40. C. ljaurica Starobogatov et Izzatulaev, 1974 & + & - & - \\
\hline \multicolumn{4}{|l|}{ family Bithyniidae Gray, 1857} \\
\hline 41. Bithynia tentaculata (Linnaeus, 1758) & + & + & + \\
\hline 42. B. curta (Garnier et Picard, 1840) & + & - & - \\
\hline 43. B. decipiens (Millet, 1843) & + & - & - \\
\hline 44. Opisthorchophorus baudonianus (Gassies, 1869) & + & + & + \\
\hline 45. O. troscheli (Paasch, 1842) & + & + & + \\
\hline
\end{tabular}


Table 2 (continuing)

Таблица 2 (продолжение)

\begin{tabular}{|c|c|c|c|}
\hline 46. O. abakumovae Andreeva et Starobogatov, 2001 & + & - & + \\
\hline 47. Paraelona socialis (Westerlund, 1886) & + & - & + \\
\hline $\begin{array}{l}\text { 48. P. milachevitchi Beriozkina et Starobogatov in Anistratenko et } \\
\text { Stadnichenko, } 1995\end{array}$ & - & - & + \\
\hline \multicolumn{4}{|l|}{ family Acroloxidae Thiele, 1931} \\
\hline 49. Acroloxus lacustris (Linnaeus, 1758) & + & + & - \\
\hline \multicolumn{4}{|l|}{ family Lymnaeidae Rafinesque, 1815} \\
\hline 50. Lymnaea (Lymnaea) stagnalis (Linnaeus, 1758) & + & + & - \\
\hline 51. L. (L.) fragilis (Linnaeus, 1758) & + & + & + \\
\hline 52. L. (Myxas) glutinosa (Müller, 1774) & + & + & - \\
\hline 53. L. (Corvusiana) kazakensis Mozley, 1934 & + & - & - \\
\hline 54. L. (Sibirigalba) sibirica (Westerlund, 1885) & - & + & + \\
\hline 55. L (Galba) truncatula (Müller, 1774) & + & + & - \\
\hline 56. L. (G.) subangulata (Roffiaen, 1868) & + & - & - \\
\hline 57. L. (Stagnicola) palustris (Müller, 1774) & + & + & + \\
\hline 58. L. (S.) archangelica Kruglov et Starobogatov, 1986 & + & + & + \\
\hline 59. L. (S.) saridalensis Mozley, 1934 & + & + & + \\
\hline 60. L. (S.) likharevi Lazareva, 1967 & + & + & + \\
\hline 61. L. (S.) atra (Schrank, 1803) & + & + & + \\
\hline 62. L. (S.) terebra (Westerlund, 1885$)$ & + & + & + \\
\hline 63. L. (S.) callomphala (Servain, 1881) & + & - & - \\
\hline 64. L. (S.) danubialis (Schrank, 1803) & + & - & - \\
\hline 65. L. (Radix) auricularia (Linnaeus, 1758) & + & + & + \\
\hline 66. L. (R.) psilia (Bourguignat, 1862) & + & + & + \\
\hline 67. L. (R.) intercisa (Lindholm, 1909) & - & + & - \\
\hline 68. L. (R.) gebleri (Middendorff, 1851) & - & + & - \\
\hline 69. L. (Peregriana) ampullacea (Rossmässler, 1835) & + & + & + \\
\hline 70. L. (P.) balthica (Linnaeus, 1758) & + & - & - \\
\hline 71. L. (P.) kurejkae Gundrizer et Starobogatov, 1979 & + & - & - \\
\hline 72. L. (P.) intermedia Lamarck, 1822 & + & + & + \\
\hline 73. L. (P.) ovata (Draparnaud, 1805) & + & + & + \\
\hline 74. L. (P.) fontinalis (Studer, 1820) & + & + & + \\
\hline 75. L. (P.) peregra (Müller, 1774) & + & - & - \\
\hline 76. L. (P.) tumida (Held, 1836) & + & + & + \\
\hline 77. L. (P.) patula (Da Costa, 1778$)$ & + & + & - \\
\hline 78. L. (P.) novikovi Kruglov et Starobogatov, 1983 & + & - & + \\
\hline 79. L. (P.) dolgini Gundrizer et Starobogatov, 1979 & + & + & + \\
\hline 80. L. (P.) napasica Kruglov et Starobogatov, 1983 & + & + & + \\
\hline 81. L. (P.) obensis Kruglov et Starobogatov, 1984 & - & - & + \\
\hline 82. L. (P.) jacutica Starobogatov et Streletzkaja, 1967 & - & - & + \\
\hline 83. L. (P.) igarkae Gundrizer et Starobogatov, 1979 & - & - & + \\
\hline 84. L. (P.) juribeica Kruglov et Starobogatov, 1984 & - & - & + \\
\hline 85. L. (P.) lagotis (Schranck, 1803) & + & + & + \\
\hline 86. L. (P.) zazurnensis Mozley, 1934 & - & - & + \\
\hline 87. L. (P.) ulaganica Kruglov et Starobogatov, 1983 & + & - & - \\
\hline 88. Aenigmomphiscola uvalievae Kruglov et Starobogatov, 1981 & + & - & - \\
\hline 89. Ae. kazakhstanica Kruglov et Starobogatov, 1981 & + & - & - \\
\hline \multicolumn{4}{|l|}{ family Bulinidae Herrmansen, 1846} \\
\hline 90. Planorbarius corneus (Linnaeus, 1758) & + & + & + \\
\hline 91. P. purpura (Müller, 1774) & + & + & + \\
\hline 92. P. banaticus (Lang in Bourguignat, 1859) & + & - & - \\
\hline 93. P. adelosius (Bourguignat, 1859) & + & + & - \\
\hline
\end{tabular}


Table 2 (continuing)

Таблица 2 (продолжение)

\begin{tabular}{|c|c|c|c|}
\hline \multicolumn{4}{|c|}{ family Planorbidae Rafinesque, 1815} \\
\hline 94. Planorbis planorbis (Linnaeus, 1758) & + & + & + \\
\hline 95.P. carinatus Müller, 1774 & + & - & - \\
\hline 96. Anisus (Vorticulus) bavaricus (Westerlund, 1885) & + & - & - \\
\hline 97. A. (Disculifer) hypocyrtus (Servain, 1888) & + & + & + \\
\hline 98. A. (D.) vortex (Linnaeus, 1758) & + & + & + \\
\hline 99. A. (D.) johanseni (Mozley, 1934) & + & + & + \\
\hline 100. A. (Bathyomphalus) contortus (Linnaeus, 1758) & + & + & + \\
\hline 101. A. (B.) crassus (Da Costa, 1778) & + & + & + \\
\hline 102. A. (Gyraulus) albus (Müller, 1774) & + & + & + \\
\hline 103. A. (G.) draparnaudi (Sheppard, 1823) & + & + & + \\
\hline 104. A. (G.) stelmachoetius (Bourguignat, 1860) & + & + & + \\
\hline 105. A. (G.) stroemi (Westerlund, 1881) & + & + & + \\
\hline 106. A. (G.) acronicus (Férussac, 1807) & + & + & + \\
\hline 107. A. (G.) kruglowiae (Johansen, 1837) & - & + & - \\
\hline 108. A. (G.) baicalicus (B. Dybowski, 1913) & + & + & - \\
\hline 109. A. (G.) borealis (Lovén in Westerlund, 1875) & - & + & + \\
\hline 110. A. (Anisus) spirorbis (Linnaeus, 1758) & + & + & + \\
\hline 111. A. (A.) leucostoma (Millet, 1813) & + & + & + \\
\hline 112. A. (A.) dazuri (Mörch, 1868) & + & + & - \\
\hline 113. A. (Torquis) laevis (Alder, 1838) & - & - & + \\
\hline 114. Armiger crista (Linnaeus, 1758) & + & + & - \\
\hline 115. A. bielzi (Kimakowicz, 1884) & + & - & - \\
\hline 116. A. eurasiaticus Prozorova et Starobogatov, 1996 & + & + & - \\
\hline 117. Hippeutis diaphanella (Bourguignat, 1864) & + & - & - \\
\hline 118. H. euphaea (Bourguignat, 1864) & + & - & - \\
\hline 119. Choanomphalus riparius (Westerlund, 1865) & + & + & - \\
\hline 120. Ch. rossmaessleri (Auerswald in A. Schmidt, 1851) & + & - & + \\
\hline 121. Segmentina clessini (Westerlund, 1873) & + & - & - \\
\hline 122. S. servaini (Bourguignat in Servain, 1881) & + & - & - \\
\hline 123. S. inniae Kruglov et Soldatenko, 1997 & + & - & - \\
\hline 124. S. molytes (Westerlund, 1885) & + & - & - \\
\hline 125. S. oelandica (Westerlund, 1885) & + & - & - \\
\hline 126. Ancylus fluviatilis (Müller, 1774) & + & - & - \\
\hline \multicolumn{4}{|c|}{ family Physidae Fitzinger, 1833} \\
\hline 127. Physa adversa (Da Costa, 1778) & + & + & + \\
\hline 128. Ph. fontinalis (Linnaeus, 1758) & + & - & - \\
\hline 129. Ph. bulla (Müller, 1774) & + & - & - \\
\hline 130. Aplexa hypnorum (Linnaeus, 1758) & + & + & - \\
\hline 131. A. turrita (Müller, 1774) & + & - & - \\
\hline 132. A. ataxiaca (Fagot, 1883) & + & - & - \\
\hline 133. Sibirenauta elongata (Say, 1821) & - & - & + \\
\hline 134. S. sibirica (Westerlund, 1876) & + & - & + \\
\hline Total & 114 & 68 & 59 \\
\hline
\end{tabular}

Equator to poles by appeal to the equator-pole asymmetry of solar energy allocation.

The highest levels of faunistic similarity were found between pairs of adjacent provinces: IRT and SOB, and SOB and NOB (Table 3).
It does not conform with an opinion of Ya.I. Starobogatov (1986), who offered to include Irtyshian province on the one hand, and two Obian provinces on the other hand, into different faunistic superprovinces, namely into Euro- 
Table 3. Faunistic similarity between zoogeographic provinces measured by means of the Ochiai' index of association

Таблица 3. Степень фаунистического сходства между зоогеографическими провинциями, выраженная с помощью индекса Очиаи

\begin{tabular}{|l|l|l|l|l|l|}
\hline PEC* & 1.00 & & & & \\
\hline LOB & 0.51 & 1.00 & & & \\
\hline MOB & 0.54 & 0.70 & 1.00 & & \\
\hline IRT & 0.47 & 0.54 & 0.69 & 1.00 & \\
\hline LYE & 0.48 & 0.61 & 0.58 & 0.42 & 1.00 \\
\hline & PEC & LOB & MOB & IRT & LYE \\
\hline
\end{tabular}

*Abbreviations of provinces' names: PEC — Pechorian; LOB — Lower Obian; MOB — Middle Obian; IRT — Irtyshian; LYE — Lower Yenisean.

pean-Central-Asian and Siberian, respectively. Our data show that the gastropod fauna of Irtyshian province is more similar to the faunas of the two Obian provinces than to the fauna of the Pechora River basin which belongs to European-Central Asian superprovince (see Table 3). However, such a contradiction has, probably, arisen due to the taxonomic bias only. Our analyses did not included bivalve species, whereas Ya.I. Starobogatov $(1970,1986)$ used both bivalve and gastropod taxa in his zoogeographical zonation. Therefore, zoogeographical studies on the Western Siberian malacofauna should be continued.

Moreover, two 'Northern' provinces under study (i.e. Lower Obian and Lower Yenisean) are more similar, in respect of its snail fauna, to each other than to the two 'Southern' (i.e. Irtyshian and Middle Obian) ones, and constitute a separate cluster in the dendrogram (Fig. 2). The gastropod fauna of Pechorian province differs clearly from the faunas of all Siberian provinces (see Fig. 2), and this may be regarded as an evidence of a some peculiarity of the Western Siberia freshwater malacofauna that is enriched with species of Eastern Siberian and even of Northern American origin as well as with endemic taxa (Starobogatov, 1970; Kruglov, Starobogatov, 1981). Eleven species (or 8.2\%) are endemics of Western Siberia. These are Cincinna antiquilina, Caspiohydrobia borealis, $C$. johanseni, Aenigmomphiscola kazakhstanica, Lymnaea napasica, L. dolgini, L. obensis, L. novikovi, L. juribeica, L. ulaganica, Anisus johanseni, which, possibly, have arisen in the Western Siberian center of speciation that, prob- ably, existed in the late Neogene (Kruglov, Starobogatov, 1981).

Gastropod species of the Western Siberia water malacofauna belong to 13 zoogeographical groups, the largest of which is the EuropeanSouth-West-Siberian one that includes 42 species, or $31.3 \%$ (Table 4). Thus, a large portion of gastropod species having a European origin does not occur in Siberia beyond its southernwestern part. Perhaps, it may be explained by severe climatic conditions of Siberia.

Nevertheless, the freshwater snail fauna of Western Siberia has, as a whole, a 'European' character, especially as compared with the malacofauna of the Eastern Siberian waterbodies. Indeed, only 44 (or 33\%) out of the species inhabiting Western Siberia do not occur in Europe, that confirms assumption of Ya.I. Starobogatov $(1970,1986)$ that those species, which migrated to Siberia from Europe during the Neogene and Pleistocene, constitute a basis of the recent freshwater malacofauna of Western Siberia. These cold-resistant species, having a boreal European origin, have replaced endemic heat-loving forms of gastropods and bivalves, which were very abundant and diverse in the neogene waterbodies of Western Siberia (Lindholm, 1932a, b; Starobogatov, 1970; Zykin, 1979). Probably, the main path of migration was situated in Northern Kazakhstan and Southern Urals. The greatest portion of European species in local faunas is observed now just here. Toward the northeast, a portion of species having either Siberian or Northern American origin increases, and a portion of European species as well as overall species richness decrease in the 
Table 4. Zoogeographic groups in the fauna of Gastropoda of inland waters of Western Siberia Таблица 4. Зоогеографические группировки брюхоногих моллюсков континентальных вод Западной Сибири

\begin{tabular}{|l|c|c|c|}
\hline \multirow{2}{*}{ Zoogeographic group } & \multicolumn{3}{c|}{ number of species } \\
\cline { 2 - 4 } & Pectinibranchia & Pulmonata & In sum \\
\hline 1. Holarctic & - & 3 & 3 \\
\hline 2. All-Palaearctic & - & 3 & 3 \\
\hline 3. European-Siberian & 2 & 12 & 14 \\
\hline 4. European-West Siberian & 7 & 15 & 22 \\
\hline 5. European-South Siberian & - & 5 & 5 \\
\hline 6. European-Central Asian & - & 1 & 1 \\
\hline 7. European-Southwest-Siberian & 17 & 25 & 42 \\
\hline 8. Siberian & 5 & 8 & 13 \\
\hline 9. Siberian-North American & 1 & 1 & 2 \\
\hline 10. Siberian-North European & 1 & 2 & 3 \\
\hline 11. West Siberian & 3 & 7 & 10 \\
\hline 12. West Siberian-Central Asian & 12 & 1 & 13 \\
\hline 13. Altayian & - & 3 & 3 \\
\hline
\end{tabular}

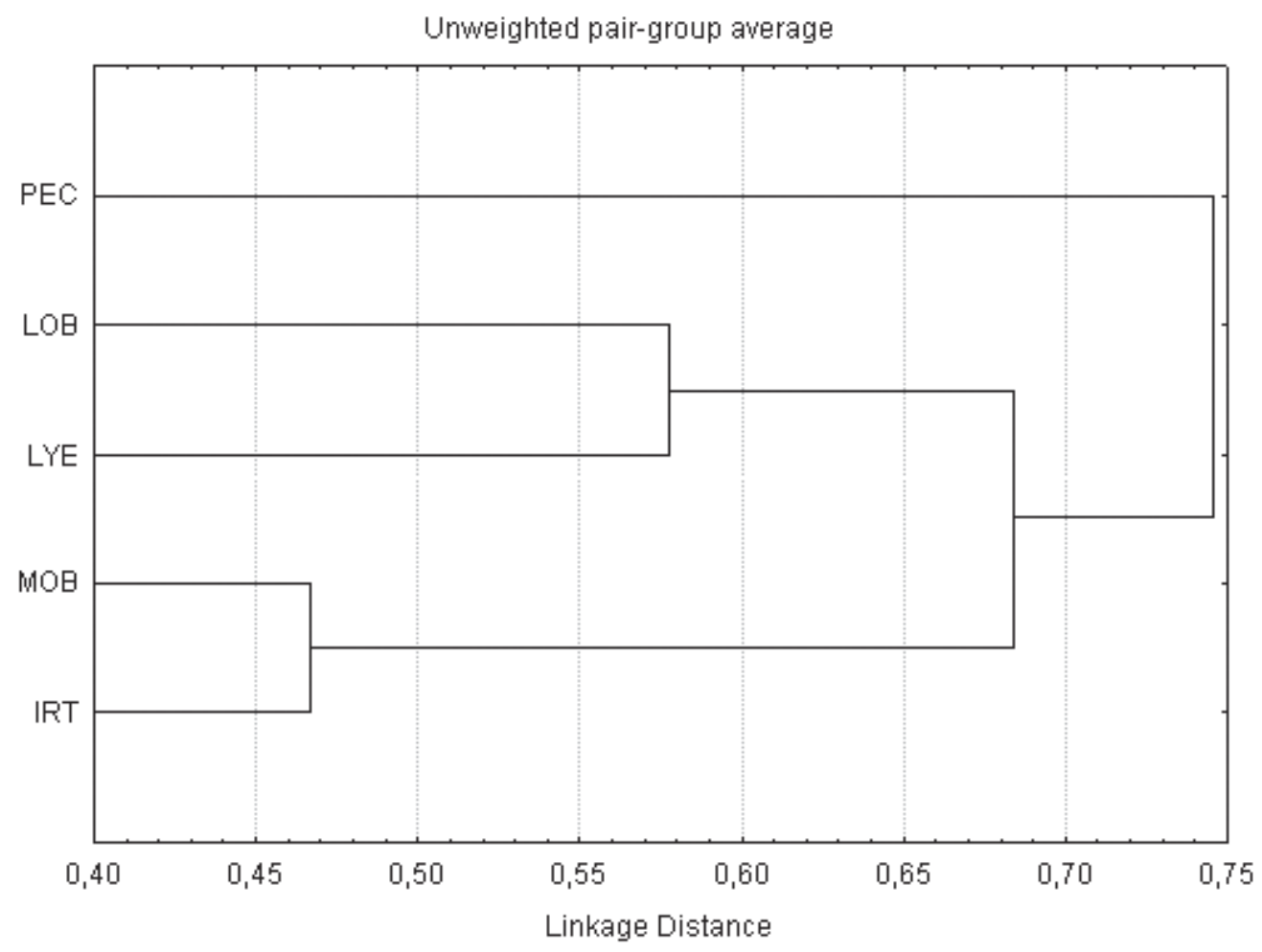

Fig. 2. Dendrogram showing similarity in species composition between provinces based on Ochiai's index of association.

Рис. 2. Дендрограмма, отражающая фаунистическое сходство между провинциями, рассчитанное с помощью индекса Очиаи. 
same direction (Andreev et al., 2004). The most peculiar is the gastropod fauna of the Yamal Peninsula that is similar in its origin and species composition to the fauna of Lower Yenisean province (Dolgin, 2001). It is the poorest local fauna in respect of species and it consists mainly of Siberian endemic forms. According to V.N. Dolgin's (2001) data, supplemented by our examination of museum collections, only 15 species of freshwater Gastropoda inhabit the Yamal waterbodies, whereas more than 60 species of snails were recorded from the waterbodies of the Ilmeny Reserve (Southern Urals, south-western part of the Irtysh River basin). The causes of it are, perhaps, twofold. First, severe climate of the Yamal Peninsula, situated north of the Arctic Circle, and, second, the absence of a large transit river, which would be a road for snails' downstream dispersal. For the greater part of Western Siberia such a function is performing by the Irtysh and $\mathrm{Ob}$ ' Rivers which flow in north direction, however, the Yamal Peninsula is situated northwestwardly of the $\mathrm{Ob}$ ' bay, and it limits greatly an ability of freshwater gastropods to reach this territory by a downstream drift.

Thus, from the faunogenetic prospect, the gastropod fauna of inland waterbodies of Western Siberia consitutes a derivative from the boreal European species complex supplemented by few autochthonous species and by migrants from Eastern Siberia and Northern America. The 'European' character of the fauna is expressed most clearly in the southwestern part of Western Siberia where boreal European species predominate.

\section{Acknowledgements}

The authors wish to thank all colleagues who kindly provided their collections of snails for examination: Dr. V.N. Dolgin (Tomsk), Dr. D.A. Razmashkin (Tyumen), A.V. Ubasskin (Pavlodar), P.V. Chashchin (Miass), M.E. Grebennikov (Yekaterinburg), L.N. Stepanov (Yekaterinburg). Besides, we are thankful to Dr. I.M. Khokhutkin, Dr. P.V. Kiyashko, L.L. Yarochnovich and N.G. Erokhin who helped us during our work in museums.

\section{References}

Andreev N.I., Andreeva S.I., Karimov A.V., Lazoutkina E.A., Vinarski M.V. 2004. The fauna of Gastropoda of the Western Siberian Plain // Abstracts of the International Symposium of Malacology, Sibiu (Romania), 19-22 August 2004. Sibiu. P.1-2.

Chernov Yu.I. 1991. [Biodiversity: essence and problems] // Uspekhi sovremennoj biologii. Vol.111. P.499-507 [in Russian with English summary].

Dolgin V.N. 2001. [Freshwater Mollusca of the Arctic and Subarctic zones of Siberia]. DSci Thesis. Tomsk: TGU. 423p. [in Russian].

Dolgin V.N., Jonahsen B.G. 1976. [Freshwater molluscs of the northern part of Western Siberia and its quantitative characteristics]//Voprosy biologii i agronomii. Tomsk: TGPI. P.67-77 [in Russian].

Frolova E.S. 1973. [Freshwater Mollusca of Northern Kazakhstan]. PhD Thesis. Tomsk: TGU. 254p. [in Russian].

Gaston K.J. 2000. Global patterns in biodiversity // Nature. Vol.405. P.220-227.

Gebler F. 1829. Notice sur le Museé de Barnaoul en Siberie // Bulletin de la Société Iimperiale des naturalistes de Moscou. T.1. P.51-59

Glöer P. 2002. Die Süßwassergastropoden Nord- und Mitteleuropas: Bestimmungschlussel, Lebensweise, Verbreitung. Hackenheim: Conchbooks. 327s.

Glöer P., Meier-Brook C. 2003. Süsswassermollusken. Ein Bestimmungsschlüssel für die Bundesrepublik Deutschland. Hamburg: Deutscher Jugendbund für Naturbeobachtung. 13 neubearb. Aufl. $136 \mathrm{~s}$.

Gundrizer V.A. 1984. [Freshwater molluses of Middle Siberia, its significance in the production of waterbodies] // Biologicheskije resursy vnutrennikh vodoemov Sibiri i Dal'nego Vostoka. Moskva. P.164-175 [in Russian].

Hawkins, B.A., Field, R., Cornell, H.V., Currie, D.J., Guégan, J.-F., Kaufman, D.M., Kerr, J.T., Mittelbach, G.G., Oderdorff, Th., O'Brien, E.M., Porter, E.E., Turner, J.R.G. 2003. Energy, water, and broad-scale geographic patterns of species richness // Ecology. Vol.84. No.12. P.3105-3117.

Kantor Yu.I., Sysoev A.V. 2005. [The catalogue of Mollusca of Russia and adjacent countries]. Moskva: KMK Scientific Press. 527 p. [in Russian].

Korniushin A.V. 2002. [On the species diversity of freshwater bivalve mollusks in Ukraine and the strategy of its conservation] // Vestnik zoologii. Vol.36. No.1. P.9-23 [in Russian with English summary].

Kruglov N.D., Starobogatov Ya.I. 1981. [A new genus of the Lymnaeidae and taxonomy of the subgenus $\mathrm{Om}$ phiscola (Lymnaea, Pulmonata, Gastropoda)] // Zoologicheskij zhurnal. Vol.60. No.7. P.965-977 [in Russian with English summary].

Kruglov N.D., Starobogatov Ya.I. 1987. [Life forms of limneids and some problems of the systematics] // Mollyuski: rezul'taty i perspectivy ikh issledovanij. Leningrad: Nauka. No.8. P.68-70 [in Russian with English summary]. 
Leshko Yu.V. 1998. [Molluscs] // Fauna Evropejskogo Severo-Vostoka Rossii. Saint-Petersburg: Nauka. Vol.5. No.1. P.1-168 [in Russian].

Leshko Yu.V., Shadrin N.Yu., Pan'kov N.N. 2001. [The fauna and zoogeographical characteristics of freshwater molluscs of Western Urals and Timan] // Fauna i ekologiya bespozvonochnykh zhivotnykh evropejskogo severo-vostoka Rossii. Syktyvkar. P.152-163 [in Russian].

Lindholm V.A. 1932a. [Molluscs from the Middle-Pliocene freshwater deposits of the southern part of Western Siberia]. Leningrad-Moskva: Geolrazvedgiz. 50p. [in Russian].

Lindholm V.A. 1932b. [Freshwater molluses from the Pliocene deposits on the Irtysh River]. LeningradMoskva: Geolrazvedgiz. 28p. [in Russian].

Malyshev L.A. 2001. [Syndromes in comparative floristics] // Evoljutsionnaya biologiya. Tomsk: Tomsk State Univ. Press. Vol.1. P.190-206 [in Russian].

Meier-Brook C. 1993. Artauffassungen im Bereich der limnischen Mollusken und ihr Wandel im 20 Jahrhundert // Archiv für Molluskenkunde. Bd.122. S.133-147.

Mozley A. 1936. The freshwater and terrestrial Mollusca of Northern Asia // Transactions of the Royal Society of Edinburgh. Vol.58. Pt.3. P.605-695.

Novikov E.A. 1971. [Freshwater molluscs of the Middle Ob’ River basin]. PhD Thesis. Tomsk: TGU. 288p. [in Russian].

Novikov E.A. 1983. [Results of studies of freshwater molluscs of Western Siberia] // Molljuski: Sistematika, ekologiya i zakonomernosti rasprostranenia. Leningrad: Nauka. No.7. P.135-137 [in Russian].

Ochiai A. 1957. Zoogeographical studies on the soleoid fishes found in Japan and its neighbouring regions. II. // Bulletin of the Japan Society of Fisheris Science. Vol.22. No.9. P.526-530.

Pesenko Yu.A. 1982. [Principles and methods of quantitative analysis in faunistic researches]. Leningrad: Nauka publ. 288p. [in Russian].
Richter G.D. 1963 (ed.). [Western Siberia]. Moskva: Soviet Academy of Sciences press. 488 p. [in Russian].

Starobogatov Ya.I. 1970. [Fauna of Molluscs and zoogeographic regionalization of inland waters of the Globe]. Leningrad: Nauka publ. 372p. [in Russian].

Starobogatov Ya.I. 1986. [The fauna of lakes as a source of data on its history] // Obshchie zakonomernosti vozniknovenia i razvitia ozer. Metody izuchenia istorii ozer. Moscow: Gidrometeoizdat Publ. P.33-50 [in Russian].

Starobogatov Ya.I. 1994. [Biodiversity of Mollusca in the inland waters, and state of its study in Russia and adjacent independent countries] // Bioraznoobrazie: Stepen' taksonomicheskoj izuchennosti. Moscow: Nauka publ. P.60-65 [in Russian].

Starobogatov, Ya.I., Bogatov, V.V., Prozorova, L.A., Saenko, E.M. 2004. [Molluscs] // Tsalolikhin S.J. (ed.). Opredelitel' presnovodnykh bespozvonochnykh Rossii i sopredel'nykh territorij. Saint-Petersburg: Nauka publ. Vol.6. P.6-492 [in Russian].

Westerlund C.A. 1877. Sibiriens Land- och Sötvatten Mollusker // Kongliga Svenska Vetenskaps-Akademiens Handlingar. Bd.14. No.1. P.1-112.

Westerlund C.A. 1884. Land- och Sottvatten-Mollusker insamlade under Vega-Expeditionen af O. Nordqvist och A. Stuxberg // Vega-Expeditionens vetenskapliga iakttagelser. Stockholm: Bejer. Bd.4. S. 143-220.

Westerlund C.A. 1897. Beiträge zur Molluskenfauna Russlands // Jezhegodnik Zoologicheskogo Muzeja Imperatorskoj Akademii nauk. Saint-Petersburg. T.2. P.117-143.

Zhadin V.I. 1952. [Molluscs of fresh- and brackish waters of Soviet Union] // Opredeliteli po faune SSSR. Leningrad: Sovetskaya nauka. No.46. P.1-376 [in Russian].

Zykin V.S. 1979. [Stratigraphy and unionids of the Pliocene of the southern part of the Western Siberian Plain]. Novosibirsk: Nauka publ. 106 p. [in Russian]. 